\title{
Indigenous and Current Practices in Organic Agriculture in Nigeria: A Review
}

\author{
Ibeawuchi I. I. ${ }^{1}$, Obiefuna J. C. ${ }^{1}$, Tom C. T. ${ }^{1}$, Ihejirika G. O. ${ }^{1}$, Omobvude S. O. ${ }^{2}$ \\ ${ }^{1}$ Department of Crop Science and Technology, Federal University of Technology, Owerri, Nigeria \\ ${ }^{2}$ Department of Crop and Soil Science, University of Port Harcourt, Rivers State, Nigeria
}

Email address:

ii_ibeawuchi@yahoo.co.uk (Ibeawuchi I. I.)

\section{To cite this article:}

Ibeawuchi I. I., Obiefuna J. C., Tom C. T., Ihejirika G. O., Omobvude S. O.. Indigenous and Current Practices in Organic Agriculture in Nigeria: A Review. Agriculture, Forestry and Fisheries. Vol. 4, No. 6, 2015, pp. 257-262. doi: 10.11648/j.aff.20150406.14

\begin{abstract}
The paper defines organic agriculture as holistic management system which promotes agro-ecosystem's health, biodiversity, biological cycle and biological activity without the external inputs of synthetic chemicals such as: fertilizers, pesticides, hormones and feed additives. Benefit include among others: high and comparable yield though could be supported by those receiving support from European community that provides monitory help to farmers as well as with conventional farming. Current practices of organic agriculture are a modification and continuation of indigenous practices that are more prominent in Nigeria. More research and funding by government and private sectors have been recommended.
\end{abstract}

Keywords: Organic Agriculture, Indigenous Crops, Current Practices, Nigeria

\section{Introduction}

Agriculture is major employer of workforce in Nigeria engaging about $70 \%$ of both the elderly and the young; male and female. Generally, man depends on plants for food, fibre, clothing, medicine, shelter etc. Thus, plant growth and yield in all ecosystems depend on the cycling and recycling of nutrients between the plant biomass and the organic and inorganic soil stores. Over the years, agriculture developed as a result of man's quest to feed himself, family and his animals. Through time man discovered that agriculture attracts various input from art, a science and also a business of producing plants and animal products for the beneficial use of mankind. Plants are primary producers in agriculture. During the process of photosynthesis, they take in carbon dioxide from the air, moisture and nutrients from the soil and by trapping the energy from sun light, convert these simple compounds into complex food materials.

Animals are secondary agricultural producers. They eat plants or parts of plants and convert the complex compounds they contain into animal products such as meat, milk, eggs, hides and wool. Primitive agriculture made use of the soil, rainfall and the local species of plants and animals as they naturally occur. Any plants and organisms which reduce the productivity of useful plants and animals were avoided or controlled. Productivity in the system was low and capable of feeding the farmers and his family alone. Due to population pressure and urbanization agricultural practices improved with use of high external inputs such as inorganic fertilizers, agro-chemicals for pest and weeds, these helped to increase productivity but with serious adverse effect on environment and man making the entire system very unsustainable. The trend in agricultural production system from indigenous to modern agriculture has developed by which agriculture is dynamic and improved overtime. Currently, there is a another strategy known as organic agriculture, which is a production system that maintains and sustains the health of soils, the ecosystem and the people living in that system and beyond. It completely relies on ecological processes, biodiversity and cycles adapted that are understood by local agricultural farmers in their conditions but exclude the use of external inputs with negative effects. Organic agricultural practices combine and interwoven in innovation, science, art, as well as business to benefit the environment and promote fair relationships and a good quality of life for all involved in it. Organic agricultural practices increases productivity by the slow release of nutrients to plants and habour as well as maintain soil biological stand. This brings about increase in productivity with little or no damage to the environment. There is need to review the indigenous and current practices of organic agriculture especially in Nigeria. A study of this nature is needed to further create awareness on indigenous 
practices of organic agriculture for proper comparison with the current practices. To further reposition agriculture for sustainable consumption and income, the knowledge of what is going on presently is needed to shape what will happen in future. This paper seeks to review the practicing of organic agriculture in order to create more awareness on the principles for which it is based, highlight the roles and problems of organic agriculture in our rural communities, review the indigenous practices and assess the current practices for proper recommendation.

\section{Meaning of Organic Agriculture}

Organic agriculture is based on production standards that require no synthetic inputs, instead using practices modeled on ecological processes to increase soil fertility and discourage pest infestation and disease infections in the fields, pens and ranges. This is to say that animals such as pigs lie in pens while cows feed on range lands. Prior the era of inorganic fertilizers, our forefather farmers usually restore fertility through the length of fallow period which may be $8-16$ years and at times 20 years. They never used anything except may be the kitchen ash, poultry manure and dirt gathered after sweeping the compound. As population keep on increasing, unknowingly, the fallow period came down from 8-16 years to 8-12 years and to 3-4 years presently. The soil is no longer fertile as a result of many factors including soil erosion, nutrient mining by crops, exposure to rain and sunlight creating crusting etc. [5] viewed organic agriculture as providing a broad set of practices that increase resilience in farms. Thus: "Organic agriculture is a holistic production management system which promotes and enhances agro-ecosystem's health including increased functional biodiversity, biological cycles and soil biological activities. It emphasizes the use of management practices in preference to the use of off- farm inputs, taking into account that, regional conditions require locally adapted systems. This is accomplished by using where possible, cultural, biological and mechanical methods, as opposed to using synthetic materials, to fulfill any specific function within the system".

This definition serves in this review as a base line for organic agriculture around the world as well as in Nigeria [5]. Countries develop their own standards from those set out by the Codex Alimentarius Commission which is a commission of collection of internationally recognized standards, codes of practice, guidelines and other recommendations relating to foods, food production and food safety. Although organic agriculture adheres to certifiable standards, farmers can do much more to base their practices in ecology than standards required. The principles of organic agriculture concerns the way people interact with living landscapes, relate to one another and shape the legacy of future generation. The International Federation of Organic Agriculture Movement IFOAM describes four principles of organic farming, on which its standards are based. Each of the principles contributes to the long term health of the farm, the surrounding environments, and the farming participants, which in turn builds resilience for the long term success of the farm. These principles of this area of knowledge include:

- Health: Organic agriculture should enhance the health of soil, plant, animals, human and planet as one and indivisible.

- Ecology: Organic agriculture should be based on living ecological systems and cycles, work with them, emulate them and help sustain them.

- Fairness: Organic agriculture should build on relationships that ensure fairness with regards to common environment and life opportunities.

- Care: Organic agriculture should be managed in a precautionary and responsible manner to protect the health and well being of current and future generations and the environment[13].Presently organic agriculture has been found to play vital role in solving or reducing to barest minimum the following:

\section{Environmental degradation:}

Overtime high intensive agriculture has resulted to the global yield gap between best practices and farmers 'fields remains large, resulting to agricultural lands that continue to shrink and with corresponding global environmental threats: erosion of biodiversity, desertification, climate change and other trans-boundary pollution become a reality [25]. Intensive agriculture contributes to over $20 \%$ of global green house gas emissions - GHGs [25], Agricultural activities affects $70 \%$ of all threatened bird species and $49 \%$ of all plant species [25]) uniform cultures have dramatically reduced the number of plants and animals used in agriculture. Currently, 1,350 breeds face extinction, with two breeds being loss every week. Biodiversity erosion is exacerbated by the loss of forest cover, coastal wet lands and other wild relatives, important for development of biodiversity and essentials for food provision, particularly in times of food crisis.

Biodiversity Protection: Protecting biodiversity at genes, species and ecosystem levels through germplasm banks and protected areas is not sufficient. The maintenance cost of gene banks are high, up to half of the material collected is in need of regeneration and "freezing" genetic resources denies thenevolution. Biodiversity is best maintained through sustainable utilization and selection by food providers. Animals that move across boundaries and ecosystems are not immune to air and water pollution. The $12 \%$ of global land areas "fenced" for nature protection are located within or around a 40 percent land surface used by agriculture and forestry [24]. Food systems should be viewed as an integral part of the ecosystem. There is a need to manage agricultural land as part of a larger landscape that explicitly considers ecological functioning [25].

\section{Self reliance, Rural Development and Nature} Conservation:

Organic agriculture offers a means to address food selfreliance, rural development and nature conservation. The goal of organic agriculture is sustainable use of biodiversity in terms of both agriculture to biodiversity and biodiversity contribution to agriculture. Organic agriculture needs functional group of species and essential ecosystem 
processes as its main "input" to compensate for the restriction on or absolute lack of synthetic input use. [25] Maintained that a close relationship exists between organic agriculture and the maintenance of biodiversity. Rules and regulations that govern certified organic agriculture and by the practical experiences of organic farmers around the world justify the success expectation of organic agriculture.

Any form of agriculture means intervention and the alteration of the processes occurring in natural ecosystem by a human being [31]. Therefore such intervention always results in environmental damage. Organic agriculture has been found to operate with minimum environmental damage $[15,34$ and 24]. Organic agriculture contributes to environmental protection and rational use of natural resources [30 and 22]. [21] made an update comparison between organic agriculture and conventional farming systems with regard to environmental performance and concluded that organic farming showed better environmental performance confidence interval than the conventional one. Crop yields obtained under organic agriculture compared with modern or conventional farming showed marked variations $20-40 \%$ in favor of conventional $[15,16,17,30]$. However there are also studies that showed that organic agriculture showed far less significant differences [26].

In a 21-year study of the agronomic and ecological performance of biodynamic, organic and conventional farming systems in Switzerland, the crop yields in biodynamic and organic system found to be 20 percent lower than in conventional, although input of fertilizer and energy was reduced by 34 to 53 percent and pesticide input by 97 percent [22]. A 22-year trial study by Cornell University in USA proved that organic farming produces the same corn and soybean yields as conventional farms, but consume less energy and utilizes no pesticides [18]. [17] made an assumption that the yield reductions associated with organic farming in Western Europe will also apply in other parts of the world. Evidence from the less developed countries including Nigeria, indicates that organic yield levels are often very similar to those achieved in conventional systems [29, 17, 36].

Several authors suggest that in the so called less developed countries and Eastern Europe, Organic yields can even be higher than conventional $[15,6]$. Organic agriculture also involves stockless organic systems. Although organic farming systems are often perceived to require both livestock and crop production enterprises to form a viable agronomic and economic unit, there may be economic and other circumstances leading to stockless farming production [23]. The stockless organic farming systems have proved to be capable of supporting soil fertility in several European regions [23]. In terms of crop yield, [23, 11] reported that the yield obtained are comparable with those achieved by other methods of organic farms. Thus, stockless organic agriculture seems to be economically viable. Another benefit of organic stockless systems is improved sanitary condition of the farm and produce especially in Europe where agri-environment has been introduced [11], In the mid nineties the proportion of stockless farms in Germany varied between 20 and 50 percent [32] while France and U.K also recorded a sustainable portion of stockless organic farmers [7].

Profitability of Organic Agriculture: Most available studies report similar or better economic performance than conventional farm, even without taking into account external costs of production $[19,16,30]$. This is mainly due to lower production cost. Organic products attract on average a 20 $50 \%$ higher price than conventional products.

Promising for less developed countries: Several authors suggested that organic farming is a promising solution for central and Eastern Europe both from the economic and environmental point of view [6, 33, 35, 37]. Options and implication of converting to organic agriculture in the less developed countries have been positively assessed. Besides, [30] observed that organic agriculture can well feed the populations of less developed countries including Nigeria.

Problems of organic agriculture:

The problems as reported in wikipedia freeencyclopedia are as follows:

\section{Soil Management:}

Plants need nitrogen, phosphorus and potassium as well as micro-nutrients, but getting enough nitrogen, and particularly synchronization so that plants get enough nitrogen at the right time (when plants need it most), is likely the greatest challenge for organic farmers.

\section{Weed Control:}

Techniques for controlling weeds have varying levels of effectiveness and including hand weeding, mulch, a natural pre-emergence herbicide, flame, garlic and clove oil, borax, pelargonicacid, solarization (which involves spreading clear plastic across the ground in hot weather for 4-5 weeks), vinegar, and various other homemade remedies. One recent innovation in rice farming is to introduce ducks and fish to wet paddy fields, which eat both weeds and insects. Note:(Oil of cloves - wikipedia, the free encyclopedia) Clove oil: it is a natural analgaesic and antiseptic used primarily in dentistry for its main ingredient eugenol. It can be purchased in pharmacies over the counter, as home remedy. There are three types of clove oil:

- Bud Oil: derived from flower-buds of Syzyguim aromaticum. Itconsists of $60-90 \%$ eugenol, eugenyl acetate, caryophyllene andother minor constituents.

- Leaf Oil: is derived from the leaves of Syzyguim aromaticum. Itconsists of $82-88 \%$ eugenol with little or no eugenyl acetate, andminor constituents.

- Stem Oil: is derive from the twigs of Syzyguim aromaticum. Itconsists of 90-95\% eugenol, with other minor constituents.

Controlling other organisms:

Organisms aside from weeds which cause problems include arthropods (e.g. insects, mites) and nematodes. Fungi and bacteria can cause diseases. Insect pests are a common problem and insecticides both non-organic and organic, are controversial due to their environmental and health effects. It may be argued in a way that to manage insect is to ignore them and focus on plant health, since plants can survive the loss of about a third of leaf area before suffering severe 
growth consequences though this assertion may not be acceptable in insects that feed on fruits to a larger extent.

Indigenous Practices in Organic Agriculture:

Development and practice or organic agriculture started in the tropics when most of the world's presently unused but arable lands were farmed [14 and 8]. In Nigeria and India more than $80 \%$ of the people work on land [8]. Due to availability of arable land then, people practiced the type of agriculture that was basically free from use of synthetic inputs.

Indigenous organic agriculture based on the farming systems involving:

Shifting cultivation or slash and burn, mixed cropping or multiple cropping, and Crop rotation were practiced.

Shifting cultivation or slash and burn:

This indigenous farming system depends on natural cycles to sustain it. Therefore the farmer farmed on a piece of land until fertility declined before moving to another fertile plot. In the beginning, the farmer had no intention to go back to the already exhausted lands. Production was mainly based on naturally accumulated nutrients resulting from fallowing. Crude implement such as hoe, matchets, axe, etc were used while the farmer and his family provided the labour. Productivity in this system was low. Due to scarcity of land resulting from increased population and urbanization fallow periods were reduced. The situation ushered in other modified forms of farming systems.

Shifting cultivation was practiced by the ancient people that are now considered a type of organic agriculture that is in practice today because the use of synthetic inputs: fertilizers, insecticides, plant growth hormones, etc were not involved. Rather the use of organic manures such as: poultry droppings, compost, farmyard and green manure were emphasized for improved crop production and soil condition [3].

Mixed Cropping or Multiple Cropping: This is the growing of two or more crops on the same piece of land. The advantages of these systems include reduction of diseases and pests, maintenance of soil conditions, facilitates vertical and horizontal variations thus, allowing cultivation of crops adapted to light and shade. Also permit phased harvesting that is in crops with different maturity period that can be phase the harvesting by harvesting the early maturing varieties before the late maturing ones. Permit phased harvesting serves as insurance as when a farmer plants two or three crops on a piece of land in an intercropping or mixed cropping system, the failure of one crop does not mean the failure of all crops, the remaining one or two crops out of the two or three planted that remained serves as an insurance to the farmer. At organic level multiple cropping received no off farm input of fertilizers while land preparation is mechanically done.

Crop Rotation:

This involves a carefully considered cropping sequence with or without a fallow period. The main feature of crop rotation is that a given combination of crops is grown in a particular sequence on the same piece of land for several years without loss of soil fertility of reduced yield. This is done to; maintain and improve soil fertility, prevent build-up of pest, weeds and soil borne diseases, control soil erosion, reduce the period of peak requirement of irrigation water and conserve soil moisture from one season to the next. In crop rotation, crops were selected on the basis of their relationship to one another to ensure complementary or supplementary relationship rather than competitive. Again, the practice depended solely on organically produced input such as: compost, farmyard and poultry manures.

Current practices:

Organic agriculture is not totally new in Nigeria. It has been practiced age long in its rudimentary form by our forefathers before the advent of inorganic fertilizations. Our forefathers practiced shifting cultivation which involved the total use of natural fertility. However, engaging in shifting cultivation, crop rotation and mixed cropping systems as means of restoring soil fertility and sustainable pest and disease control without the use of agrochemicals [4]. Current practices in Nigeria for instance are based on and are still rooted in the indigenous systems since organic agriculture is not yet certified [4]. However, current practices of organic agriculture is a modification of the already existing practices with more attention on creation of integrated, humane, environmentally and economically viable agricultural systems.

Agroforestry:

This is an integrated approach of using the interactive benefits from combining trees and shrubs with crops and/or livestock Agroforestry was introduced to Nigeria in 1926 by International Council for Research in Agroforestry [9]. Practical applications of agroforestry evolve from:

- Traditional (through experience by generation of farmers).

- Modern (with the help of agricultural science) such as: shelter belt and hedgerow barriers. Recent/current (evolved with the help of research in agroforestry)

- Alley cropping and improved fallows.

Major products in this system include:

Timber, Fuel wood and Fodder [2] reported the practical applications of agroforestry as following:

- Live fences to control animal movement in the farmstead. This couldbe (a) live stakes serving as fences (b) hedges, example: Gliricidia sepuim (extracts obtained from its leaves is used to remove external parasites in animals, farmers in Latin America often wash their livestock with a paste made of crushed $\mathrm{G}$. sepuim leaves to ward off torsalos) (http://en.wikipedia.org/wiki/Gliricidia_sepuim).

- Hedgerow barriers: Are trees planted along contours of sloping lands to check erosion and provide organic matter through leave fall. Extensive root system improves soil structure, example: Pterocarpus specie (oha), tender leaves also used as vegetable and trunk used as timber.

- Windbreaks and shelter belt: planted to protect community and their lands from strong wind, example: Casuarina species, Azadirachta indica, Leucaena and Senna species. 
- Parklands (scattered trees): common type of agro forestry system in the tropics [2]. Trees are pruned and used as fodder.

- Alley cropping: it is a system in which trips (alleys) of annual crops are grown between rows of trees or shrubs. The trees used are mainly Cassia siamea, Gliricidia sepuim and Leucaena leucocephala and are capable of fixing nitrogen.

- Improved fallows: Current practices involving the use of fast growing leguminous species to shorten the long period inherent in the indigenous shifting cultivation practice.

Furthermore, agroforestry systems can be classified based on the basic components of woody perennials, herbaceous plants and animal components as: (a) agrosilvicultural system (production of woody plants and seasonal plants) (b) silvopastoral system involving production of woody plant species and livestock (c) agrosilvopastoral system (production of woody plant species, seasonal plants and livestock).

Intercropping/Multiple Cropping/Mixed Cropping:

Involve planting of two or more crops on the same piece of land in such a way that compatibility is maintained within the crop communities. In the system soil fertility is maintained by use of leguminous crops with non-leguminous ones [12, 28].

Bush Fallow System:

This is still in practice in areas where land for agriculture is available. However, production under fallow system is at a subsistence level even in the current practices. One feature note-worthy is absolute, elimination of synthetic input especially in the rural farming communities. One cannot conclusively divorce the use of synthetic input with large farms owned by cooperative societies under fallow systems.

\section{Conclusion and Recommendation}

From literature reviewed, organic agriculture appears to be a system of agriculture that preserve ecosystem, biodiversity and maintains sustainable food and health of humans. However, information on current practices in the Africa especially in Nigeria is not enough to compare the profitability of organic farming and conventional farming as is the case in advance countries: Europe and America. It is therefore recommended that more research work on organic agriculture should be encouraged through funding by government at all levels - federal, state and local government. Organic agriculturist should be given certificate and grant awards, and their organic product certified at subsidized rates for their sustained income generation through sales of such certified products at premium prices.

\section{Refernces}

[1] Agroforestry Wikipedia, the free encyclopedia. (http://en.wikipedia.org/wiki/Agroforestry).

[2] Agromisa (2003). Agroforestry CTA. Wageningen Netherlands.
[3] Asiegbu I.E. and Oikeh S.O. (1993). Growth and yield of tomato to sources andrates of organic manure in ferralitic soils. Bioresource Technology. 45: 21-25.

[4] Atungwu, J.J., Aiyelaagbe, I.O.O., Sobowale, P.A.S., Oni, A.O. and Garba, S.H., (2009). Integrating African Traditional Farming and Organic Agriculture. In: Organic Agriculture for Health, Wealth and Environmental Conservation. Proceedings of the fifth national conference of organic agricultural project intertiary institutions in Nigeria. FUTO. November, 15-19, 2009.

[5] Boron, S. (2006) Building resilience for an unpredictable future: How organic agriculture can help fanners adapt to climate change, FAO Rome, August2006. P6.

[6] Buys, J. (1993) "Conversion Towards organic agriculture in Russia - A preliminary study" Biological Codex Alimentarius commission (2001). Organically produced foods. Rome, Italy: FAO AND who 77pp.

[7] David, C., B.; (1996). Towards modeling the conversion of stockless farming to organic fanning. On-farm research in south East of France. In New Research in organic Agriculture. N. H. Kristensen and H. Hogh-Jensen pp 23-27. TholeyTheley., IFOAM: 23-27.

[8] Evans, J. (1992). Plantation forestry in the tropics (second edition). Oxford University press Inc. New York. P6.

[9] Gholz, H. L., (1987). Agroforesty: realities, possibilities, and potentials.(http://books.google.com/books7id-

Y1YflgzthEsC\&p^PA137\&Ipg=PA137\&dq^Year+agrofores1r $\mathrm{y}+$ came + mto+mgeria\%3F\&l\&sig=pLhySxcjWsl sHueqfvd6vOsji3g\&hlen).

[10] Gliricidia sepuim Wikipedia, the free encyclopedia. (http://en.wikipedia.org/wiki/Gliricidiasepuim).

[11] Huxham, S. K., (2005). The effect of conversion strategy on theyield of the first organic crop. Agriculture Ecosystems and Environment 106(4) 345-357.

[12] Ibeawuchi, I.I. and Ofoh M.C. (2000). Productivity of maize cassava/food legume mixtures in south-eastern Nigeria. Nig. J. of Agric. Rural Development 1(1): 19.

[13] International federation of organic agriculture movement (2006). The IFOAM normsfor organic production and processing. Version 2005 Bonn, Germany.

[14] Kellogg, C.E. and Orvedai, A.C. (1996). Potentially arable soils of the world andcritical measures for their use. Advances in Agronomy. 21, 109-70.

[15] Lampkin, N. (1990). Organic farming. Ipswich, farming press Books.

[16] Lampkin, N. (1992). The economic implication of conversion from conventional to organic fanning systems. Ph.D. Thesis, Dept of economics and agricultural economics, university of Wales, aberystwyth.

[17] Lampkim, N. (1999). Converting Europe- The potential for organic farming as mainstream. Paper presented to 1 th National Organic fanning conference. Cirencester.

[18] Lang, S.S. (2005) Organic farming produces same corn and soybean yields as conventional farms but consumes less energy and no pesticide. Cornell university News Service. 
[19] LEI (1990). Productie en atzet Van BD- en Eko-Produkten (production end economics or bio-dynamic food). National agro-economic institute of the whether lands. Band 2. LEI medelingen 425, Den Haeag. 89p.

[20] Mader, P. (2002). Soil fertility and biodiversity in organic fanning. Science 296(5573): 169-1697.

[21] Mader, P. (2004). Soil fertility in sustainable farming system. KSALT, Journal of the Royal Swedish Academy of Agriculture and Forestry 143 (1): 37-40. Oil of cloves wikipedia, the free encyclopaedia, (http://en.wikipedia.org/wiki/oil_of_cloves).

[22] Pretty, J.N. (1995). Regeneration agriculture: policies and practices for sustainability and self-Reliance London, Washington. National academy press, Action Aidand Vikas.

[23] Philipps L. and Welsh J.P. (1999). Ten years experience of allarable rotations. Designing and testing crop rotations for organic farming. Foulum, Danish Research Centre for organic fanning.

[24] Scialabba, E.N and C. Hattam, Eds. (2002). Organic agriculture, environment andfood security. Environmental and natural.

[25] Scialabba, E. N. (2003). Organic agriculture: The challenges of sustaining food production while enhancing biodiversity. United Nations. The matic Group meeting on wild life, biodiversity and organic agriculture. Anakara, Turkey, 15-16 April 2003, FAO Corporate documents repository.

[26] Stanhill, G. (1990). The comparative productivity of organic agriculture. Agriculture, Ecosystems and Environment. Vol30:1:1-26.

[27] The encyclopedia of organic gardening (1978) organic matter. Rodale press, inc. U.S.A. 814-819.

[28] Tom, C.T. and Asiegbu, I.E. (2002). Evaluation of short duration pigeon peacultivars in intercrop with FARZ-7 maize in derived savanna of Nigeria. International journals of agricultural science. Vol.2.

[29] Van Elzakker, B. R. Witte et al. (1992). Benefits of diversity. New York. UNDP United Nations Development Programme.

[30] VanMansvelt, J. D. and J. A. Mulder (1993). European feature for sustainable development: a contribution to the dialogue. Landscape and urban planning: 27: 67-90.

[31] Van Mansvelt, J.D. and D. Znaor (1999) Criteria for the abiotic and biotic realm: environment and ecology. Checklist for sustainable landscape management. J.D. Van Mansvelt and M.J. Lubbe. Amsterdam-Lausanne-New York, Oxford, Shannon, Scingapore, Tokio, Elsevier.

[32] Von Fragstein P. (1966). Organic arable farming a contradiction? Fourth congress of the ESA-Book of Abstracts, Colmar Cedex, European Society Agronomy.

[33] Znaor, D. (1994) Ecological Agriculture: Analysis of the most commonly criticized aspects. Why shall Estonian Agriculture be Ecological? Proceedings of the international conference heed in tartu June 13, 1994; centre of Ecological Engineering tartu.

[34] Znaor, D. (1995) Ekoloska Poljoprivreda suitrasnjice Ecological agriculture of tomorrow. Zagreb, Nakladin Zavod Globus.

[35] Znaor, D. (1997) what future for sustainable agriculture? Danube watch 3(2): 2-3.

[36] Znaor, D. and H. Kieft (2000). Environmental impact and macro-economic feasibility of organic agriculture in the Danube River Basin. The world grows organic: Proceedings of the 13th international IFO AM Scientific conference Basel, Switzerland.

[37] Znaor, D. (2002): "Contribution of organic agriculture to macroeconomic and environmental performance of the countries with economic in transition". Vagos research papers 53(6) Lithuanias University of agriculture, Akademija. 